\title{
STRATEGI MEDIASI DALAM MENYELESAIKAN KONFLIK KEKERASAN DALAM RUMAH TANGGA BERBASIS KESETARAAN GENDER
}

\author{
${ }^{1}$ Nunung Nurjanah \\ ${ }^{2}$ Bunyamin Maftuh \\ ${ }^{3}$ Elly Malihah \\ Program Studi Pendidikan Kewarganegaraan \\ Pascasarjana Universitas Pendidikan Indonesia \\ Nunungnurjanah11@upi.edu,ellyms@upi.edu,
}

\begin{abstract}
Abstrak
Kekerasan dalam rumah tangga sebagai suatu konflik yang salah satu sumbernya yakni relasi yang timpang antara suami dan isteri yang berakar pada budaya patriakhi yang menempatkan peran, fungsi, dan tanggung jawab yang bebeda pada laki-laki dan perempuan. Dalam mengatasi persoalan kekerasan dalam rumah tangga tidak cukup dengan melihat pemicu konflik yang mengakibatkan tindak kekerasan yang dialami oleh salah satu pihak, yang sebagain besar perempuan, diperlukan pemahaman akan akar persoalan tersebut. Artikel ini membahas mengenai makna kekerasan dalam rumah tangga, factor faktor penyebab kekerasan dalam rumah tangga, bagaimana keterkaitan kekerasan dalam rumah tangga dengan konsep gender. Diakhir artikel ini, diperoleh gambaran mengenai strategi mediasi berbasis kesetaraan gender dalam mengatasi kekerasan dalam rumah tangga.
\end{abstract}

Kata kunci : gender, kekerasan, rumah tangga, mediasi.

\begin{abstract}
Domestic violence as a source of conflict is an unequal relationship between husband and wife rooted in a patriarchal culture that places different roles, functions, and responsibilities on men and women. In overcoming the problem of domestic violence it is not enough to look at the triggers of conflict that result in acts of violence experienced by one of the parties, who are mostly women, an understanding of the root of the problem is needed. This article discusses the meaning of domestic violence, the factors that cause domestic violence, how the relation of domestic violence to the concept of gender. At the end of this article, an overview of gender equality-based mediation strategies is obtained in dealing with domestic violence.
\end{abstract}

Keywords: gender, violence, household, mediation.

\section{Pendahuluan}

Kekerasan dalam rumah tangga merupakan gambaran suatu konflik yang terjadi pada tingkatan domestik namun berakar pada struktur sosial budaya patriakhi, sehingga kekerasan dalam rumah tangga dapat ditemukan hampir disemua masyarakat. Sebagaimana dinyatakan oleh Conell bahwa budaya patriakhi terlembagakan pada kehidupan sosial yang luas, dan 
Nunung Nurjanah, Bunyamin Maftuh, Elly Malihah Vol 5 No 1

ISSN : 2541-6995

E ISSN : 2580-5517

budaya tersebut tercermin dalam struktur patriakhi yang terdapat dalam kehidupan keluarga, dan mendasari bagaimana perempuan mempelajari perannya sebagai istri yang ahrus melayani suami dan melakukan berbagai pelayanan domestik (Conell, 2006: 123). Untuk memahami dan mampu ambil bagian dalam menyelesaikan konflik tersebut, perlu menggunakan perspektif gender sehingga dapat memahami akar persoalan tidak sebatas pada permukaan masalah.

Dalam banyak masyarakat, kekerasan dalam rumah tangga dipandang sebagai hal yang dapat diterima, dan merupakan suatu urusan domestik sehingga pihak lain tidak perlu ikut campur. Manakala ada upaya untuk menyelesaikan persoalan kekerasan dalam rumah tangga yang dilakukan oleh pihak keluarga, maka upaya yang dilakukan cenderung tidak netral atau ada upaya membela salah satu pihak yang dipandang benar (biasaya yang memiliki posisi superior) sesuai dengan norma yang berlaku dimasyarakat, dalam hal ini, laki-laki (dalam masyarakat dengan budaya patriakhi) berpotensi selalu memiliki kesempatan untuk dimenangkan manakala dilakukan upaya penyelesaian konflik, dan perempuan hampir selalu berada pada posisi pihak yang bersalah. Dalam hal ini, diperlukan keteribatan pihak ketiga yang berperan sebagai mediator dengan menggunakan perspketif gender, sehingga kesetaraan gender dalam mediasi yang dilakukan dapat terwujud dan solusi atas konflik tersebut dapat diterima oleh semua pihak tanpa ada yang dirugikan, sebagaimana dinyatakan oleh Mayer (2000 : 200) bahwa

"In-house mediators in organizations, village elders in mediative roles, and family members who try to reconcile differences among other family members may not be neutral or impartial. What is required is that the mediator tries to help the parties interact with each other more effectively or work out an agreement that they all can accept".

Diperlukan pihak ketiga dalam menyelesaikan konflik keluarga yang tidak hanya bersikap netral, namun berkomitmen untuk memposisikan pihak yang terlibat konflik, dalam hal ini suami dan isteri dalam posisi yang setara yang memiliki hak yang sama untuk didengar, dihargai, dan diakomodir pandangan maupun tuntutannya.

Kekerasan dalam rumah tangga tidak dapat dilepaskan dari relasi laki-laki dan perempuan yang tidak setara, dimana kondisi ini berakar pada budaya patriakhi. Budaya patriakhi yang melekatkan fungsi, peran, dan tanggung jawab yang berbeda antara laki-laki dan perempuan dengan menempatkan diranah domestik sedangkan laki-laki diranah publik berimplikasi pada relasi yang tidak setara karena laki-laki dan perempuan memiliki akses yang berbeda terhadap sumber daya yang diperlukan dalam menjalankan kehidupan dan dalam 
Nunung Nurjanah, Bunyamin Maftuh, Elly Malihah Vol 5 No 1

ISSN : 2541-6995

E ISSN : 2580-5517

memberikan kontribusi bagi kehidupan yang lebih luas. Subordinasi perempuan dalam relasi keluarga berpotensi menempatkan perempuan pada posisi yang rentah menghadapi kekerasan dalam rumah tangga. Sebagaimana dinyatakan oleh Jowkes bahwa Kekerasan terhadap perempuan merupakan demonstrasi kekuatan laki-laki yang disandingkan dengan kekuatan perempuan yang lebih rendah. Di mana perempuan memiliki status rendah, mereka sering memiliki persepsi diri yang negatif tentang potensi diri dan kemampuan sosial dan ekonomi untuk meninggalkan suatu hubungan dan kembali ke keluarga mereka atau hidup sendiri, dan dengan demikian sangat dibatasi dalam kemampuan mereka untuk bertindak melawan pelaku kekerasan. (Jowkes, 2002 : 1427). Ketergantungan perempuan terhadap laki-laki sebagai akibat dari keterbatasan akses perempuan untuk memperoleh pendidikan atau melakukan aktifitas publik termasuk dalam bidang ekonomi sehingga memiliki kemandirian finansial. Untuk memutus mata rantai kekerasan dalam rumah tangga harus menggunakan pendekatan kultural, dengan mulai mengkaji ulang nilai-nilai yang diksriminatif dan membatasi hak pihak tertentu dalam hal ini perempuan untuk diperlakukan secara sama sebagai sesama warga negara dan anggota masyarakat. Selain itu, dalam konteks penyelesaian konflik rumah tangga yang mengandung kekerasan, diperlukan pelibatan pihak ketiga yang memiliki perspektif gender dalam melakukan mediasi, sehingga hak semua pihak yang berkonflik baik laki-laki maupun perempuan dapat diakomodir.

Kekerasan dalam rumah tangga tidak muncul hanya dari faktor tunggal, namun biasanya dipicu oleh berbagai faktor dengan satu faktor pemantik. Untuk memahami dan mampu melakukan mediasi atas konflik kekerasan dalam rumah tangga, perlu dipahami dulu faktor penyebab konflik sehingga solusi atas konflik yang terjadi memperhatikan kesetaraan para pihak yang bersengketa sehingga kepentingan semua pihak dapat diakomodir. Berbagai faktor menjadi dasar pemicu konflik kekerasan dalam rumah tangga baik berkenaan dengan personal, ekonomi, sosial, maupun nilai budaya yang berbeda. Sebagaimana dinyatakan oleh Menurut Azeez Oyediran kekerasan yang didapi perempuan dalam kehidupan rumah tangga dipicu oleh berbagai faktor baik pada tingkatan individual, micro,exo, dan pada tingkatan makro) menegaskan norma budaya yang membenarkan penggunaan hukuman berupa kekerasan pada perempuan. Pada tingkatan individual, keterbatasan tingkat pendidikan perempuan dan rendahnya akses perempuan untuk memperoleh pekerjaan mewakili faktor ketidakmampuan perempuan. Pada tingkatan micro atau dalam konteks kehidupan rumah tangga, perempuan kurang memiliki otonomi dalam membuat keputusan mengenai barang- 
Nunung Nurjanah, Bunyamin Maftuh, Elly Malihah Vol 5 No 1

ISSN : 2541-6995

E ISSN : 2580-5517

barang yang dibeli untuk keperluan keluarga, memposisikan perempuan pada resiko menghadapi kekerasan rumah tangga, ketika barnag yang dibeli tidak sesuai dengan apa yang dibolehkan atau dibenarkan untuk dibeli menurut suami. Pada tingkatan masyarakat yang lebih luas, lingkungan politik dan ekonomi (seperti terbatasnya layanan bantuan hukum bagi perempuan untuk memperoleh kehidupan yang lebih baik atau bagi perempuan yang menghadapi kegagalan dalam kehidupan keluarga untuk memperoleh dukungan) yang menegaskan berlangsungnya kekerasan dalam rumah tangga. (Azeez Oyediran dalam Genus, 2016). Posisi timpang yang dihadapi perempuan dalam budaya patriakhi menciptakan relasi yang tidak setara dalam kehidupan rumah tangga, sehingga berpotensi memicu kekerasan dalam rumah tangga, yang korbannya sebagian besar adalah perempuan.

\section{METODE PENELITIAN}

Penelitian ini merupakan penelitian kepustakaan, menurut Studi pustaka adalah serangkaian kegiatan yang berkaitan dengan metode pegumpulan data pustaka, membaca dan mencatat serta mengolah bahan penelitian (Zen, 2014). Sumber data yang digunakan dalam penelitian ini merupakan sumber data sekunder. Menurut Margono, data sekunder adalah data yang terdapat dapam berbagai kepustakaan (Margono, 2010). Penelitian ini menggunakan berbagai literature baik buku mapun junal nasional maupun internasional.

\section{HASIL PENELITIAN DAN PEMBAHASAN}

\section{Kajian konseptual Ketidakadilan Gender dan kekerasan dalam keluarga}

Kekerasan dalam rumah tangga merupakan suatu gambaran dari konflik yang terjadi dalam konteks rumah tangga namun memiliki akar yang bersifat struktural yakni berkenaan dengan struktur budaya patriakhi yang menjadi salah satu penopang kultur sebagian besar masyarakat termasuk diera modern saat ini. Gambaran nyata bahwa masyarakat modern saat ini masih terikat dengan budaya patriakhi dengan salah satu dampak yag mengikuti yakni kekerasan diranah domestik (kekerasan dalam rumah tangga) secara jelas dinyatakan oleh Sekretaris jendral PPB Antonio Guterres yang mendesak pemerintah untuk melindungi perempuan (dari kekerasan dalam rumah tangga) menghadapi pendemi Corona virus (TheJakartaPost.com, 6 April 2002). Meskipun terdapat pergeseran nilai yang mengarah pada terwujudnya kesetaraan dan keadilan gender sebagai bagian dari perlindungan dan penerapan hak asasi manusia, namun masih mengahadapi jalan panjang untuk sampai pada kondisi yang 
Nunung Nurjanah, Bunyamin Maftuh, Elly Malihah

Vol 5 No 1

ISSN : 2541-6995

E ISSN : 2580-5517

memposisikan secara setara laki-laki dan perempuan (kesetaraan gender) sehingga kekerasan dalam rumah tangga yang secara umum korbannya lebih banyak perempuan, tidak lagi terjadi.

Atas dasar tersebut, memahami kekerasan dalam rumah tangga tidak dapat dilepaskan dari konsep gender. Sebagaimana dinyatakan oleh Rani et all bahwa

"Social values, norms, and gender roles in a patriarchal society are conveyed within social groups and diffused from generation to generation. Acceptance of wife-beating is premised on the patriarchal norm of male domination. The effects of changes and adoption of foreign values can alter the social learning process by encouraging individuals (including women) to challenge established social values and question those that cause harm/are no longer acceptable". (Rani et all dalam Azeez Oyediran, $2016: 3$ ).

Dengan kata lain dipahami bahwa nilai, norma dan peran gender dalam masyarakat dengan budaya patriakhi disosialisasikan dari generasi ke generasi untuk tetap memelihara norma tersebut. Dalam masyarakat dengan budaya patriakhi, pemukulan terhadap perempuan ditoleransi dan mencerminkan dominasi laki-laki atas perempuan. Akses pendidikan yang disertai dengan pengenalan nilai-nilai baru yang mensosialisasikan kesetaraan dan menentang nilai sosial yang telah mapan mendorong penolakan atas nilai-nilai lama yang diskriminatif dan tidak adil. Lebih lanjut dinyatakan oleh Rani dkk bahwa Dalam masyarakat patriarki, pelanggaran terhadap peran gender baik yang dilakukan oleh laki-laki maupun perempuan merupakan suatu kondisi yang membenarkan tindakan kekerasan. (Azeez Oyediran, $2016: 3$ ). Kekerasan dalam rumah tangga pada masyarakat dengan budaya patriakhi dipandang sebagai suatu kondisi yang dapat diterima dan dianggap sebagai sanksi atas ketidakpatuhan terhadap peran gender yang melekat pada masing-masing pihak (laki-laki dan perempuan), meskipun demikian, lebih banyak perempuan yang mengalami kekerasan dalam rumah tangga dibanding laki-laki.

Sebagai pihak yang memiliki posisi yang tidak setara dalam struktur patriakhi, perempuan menghadapi berbagai bentuk ketidakadilan termasuk menghadapi kekerasan dalam rumah tangga. Sebagaimana dinyatakan oleh Young bahwa bentuk-bentuk penindasan atau ketidakadilan yang dihadapi oleh perempuan sebagai salah satu kelompok minoritas sebagaimana dinyatakan oleh Young yang teridiri dari: eksploitasi, marginalisasi, ketidakberdayaan, imperialisme budaya, kekerasan yang dilakukan secara acak, pelecehan yang dilakukan atas dasar kebencian atau ketakutan. (Young dalam Kymlicka, 1995 : 145). Kekerasan merupakan salah satu bentuk ketidakadilan yang dihadapi perempuan hingga dewasa ini. Ketiakdilan gender memposisikan perempuan sebagai pihak yang subordinat dan 
Nunung Nurjanah, Bunyamin Maftuh, Elly Malihah Vol 5 No 1

ISSN : 2541-6995

E ISSN : 2580-5517

sukar menghindari berbagai bentuk ketidakadilan yang dihadapi. Penegasan atas relasi gender yang tidak setara antara laki-laki dan perempuan, dinyatakan oleh Jowkes bahwa Kekerasan terhadap perempuan merupakan demonstrasi kekuatan laki-laki yang disandingkan dengan kekuatan perempuan yang lebih rendah. Di mana perempuan memiliki status rendah, mereka sering memiliki persepsi diri yang negatif tentang potensi diri dan kemampuan sosial dan ekonomi untuk meninggalkan suatu hubungan dan kembali ke keluarga mereka atau hidup sendiri, dan dengan demikian sangat dibatasi dalam kemampuan mereka untuk bertindak melawan pelaku kekerasan. (Jowkes, 2002 : 1427). Relasi gender yang tidak setara dan pembatasan peran perempuan yang hanya diranah domestik menjadikan perempuan memiliki persepsi yang kurang positif tentang dirinya baik sebagai pribadi maupun sebagai bagian dari komunitas yang lebih luas dan kompleks yang mengakibatkan keterbatasan pilihan yang diambil oleh perempua, termasuk manakala menghadapi kekerasan dalam keluarganya, maka pilihan yang dimiliki hanya tetap bertahan dalam keluarga dengan resiko selalu menghadapi kekerasan atau kembali pada keluarga, dan itu bukan pilihan yang mudah karena dalam masyarakat patriakhi, perempuan seringkali dipersalahkan atas berbagai permasalah keluarga karena dianggap tidak dapat menjadi istri yang baik, dan pilihan lainnya yakni memilih untuk sendiri, pilihan ini tidak selalu mudah karena keterbatasan perempuan dalam pengetahuan dan keterampilan serinngkali memposisikan perempuan tidak mandiri secara ekonomi, sehingga pilihan ini seringkali mengarahkan perempuan pada kondisi lain yang tidak kalah rumit, yakni dalam dalam jerat human traffiking. Dinyatakan oleh Kennedy bahwa Kekerasan dikaitkan dengan produk ketidaksetaraan, baik dalam bentuk keuntungan bagi salah satu pihak. Karena ketidakadilan sosial ekonomi di tingkat masyarakat atau masyarakat semakin terbukti penting dalam bentuk kekerasan lainnya. (Kennedy, 1997). Ketidaketaraan gender yang memberikan batasan peran yang tegas antara laki-laki dan perempuan, dimana laki-laki memiliki peran di ranah publik, dan perempuan diposisikan diranah domestik menjadikan perempuan tergantung secara sosial ekonomi, dan kondisi ini berpotensi mennghadapi kekerasan dalam keluarga.

Diperlukan upaya yang sistematik agar terdapat perubahan struktur sosial yang lebih berkeadilan gender, termasuk peran serta keterlibatan gerakan perempuan sehingga kekerasan dalam keluarga sebagai bagian yang tidak terpisahkan dari relasi yang timpang antara laki-laki terhadap perempuan dapat dihindari. Sebagaimana dinyatakan oleh Lang bahwa kaum feminis berinisiatif untuk mendorong persoalan ketidakadilan gender yang selama ini dirasakan oleh perempuan untuk memperoleh perhatian sehingga perempuan memiliki posisi yang setara 
Nunung Nurjanah, Bunyamin Maftuh, Elly Malihah Vol 5 No 1

ISSN : 2541-6995

E ISSN : 2580-5517

dengan laki-laki dan memperoleh pengakuan atas hak yang sama dengan laki-laki. (Lang, 1997, dalam Jalusic, 2002). Pengakuan atas kesetaraan hak antara laki-laki dan perempuan sebagai langkah awal dalam memutus kekerasan yang dihadapi terutama oleh perempuan, meskipun terdapat korban laki-laki yang mengalami kekerasan dalam keluarga, namun mayoritas kondisi tersebut dihadapi perempuan.

Kekerasan dalam rumah tangga sebagai persoalan yang dihadapi perempuan dihampir semua negara di dunia, sebagaimana ditemukan di negara-negara Afrika, sebagaimana ditunjukan berdasarkan hasil penelitian Koeng (2003) bahwa "Domestic violence is also pervasive in sub-Saharan Africa”. (Koenig et al. 2003; Kimani 2007; Tenkorang et al. 2013; Oyediran and Cunningham 2014; Solanke 2014; Wekwete et al. 2014). Kekerasan dalam rumah tangga yang dihadapi perempuan di sub -Sahara Afrika tidak dapat dilepaskan dari nilai dan norma yang melekat pada masyarakat yang mentolelir dan menguatkan praktek kekerasan yang dihadapi perempuan (Kim and Motsei 2002; Tenkorang et al. 2013). Selain Subsahara Afrika, kekerasan dalam rumah tangga cukup tinggi ditemukan di Nigeria yakni sekitar 15.6\% perempuan Nigeria dilaporkan mengalami kekerasan dalam rumah tangga. (Solanke 2014). Kekerasan yang dihadapi perempuan Nigeria tidak dapat dilepaskan dari kultur yang hidup pada masyarakat dimana kali-laki sebagai kepala rumah tangga yang harus dipatuhi oleh seluruh anggota keluarga termasuk perempuan sebagai istri. Ketidakpatuhan seorang istri dipandang sebagai dasar untuk melakukan kekerasan dalam rumah tangga sebagai upaya untuk "mengajari/mendidik" perempuan agar patuh pada suami. Dalam hal ini, kekerasan dalam rumah tangga yang dialami perempuan diterima atau ditolelir sebagai bagian dari hal yang lumrah dan dapat diterima. Data mengenai jumlah tindak kekerasan dalam rumah tangga yang ada, belum mencerminkan kondisi yang sebenarnya, seperti fenomena gunung es. ((Hindin 2003; Lawoko 2006 dalam Azeez Oyediran, 2013 : 2). Dari berbagai hasil penelitian yang menunjukan bahwa perempuan masih terkungkung dalam beragam bentuk ketidakadilan gender, kondisi ini secara nyata ditunjukan pada data penelitian yang menunjukan tingkat kekerasan dalam rumah tangga yang masih tinggi diharapi oleh perempuan. Ditegaskan oleh Lawoko bahwa sebagian besar hasil penelitian menunjukan bahwa masyarakat patriakhis mengharapkan perempuan untuk melakukan peran yang secara tradisi melekat pada mereka seperti melahirkan, menjaga rumah, patuh pada suami dan melayani kebutuhan suami. (Hindin 2003; Oyediran and Isiugo-Abanihe 2005; Rani et al. 2004; Lawoko 2006; Lawoko 2008). Kekerasan yang terjadi dalam rumah tangga berakar pada budaya patriakhi yang memposisikan 
perempuan secara subordinat (tidak setara) dalam kehidupan rumah tangga dimana perempuan dituntut untuk hanya mematuhi keputusan atau aturan yang dibuat oleh suami yang memiliki posisi superior sebagai kepala keluarga, penggunaan kekerasan untuk memastikan kepatuhan dipandang sebagai hal yang dapat diterima termasuk sebagai suatu sanksi atas "ketidakpatuhan”yang dilakukan oleh perempuan sebagi seorang istri.

\section{Kajian konseptual faktor penyebab kekerasan dalam rumah tangga}

Perempuan hingga saat ini masih menghadapi berbagai bentuk kekerasan dalam rumah tangga yang dipicu oleh berbagai faktor. Sebelum dikaji mengenai faktor - faktor penyebab kekerasan yang dihadapi perempuan. Namun, akan dikemukakan terlebih dahulu mengenai bentuk kekerasan dalam rumah tangga yang dihadapi perempuan, sebagaimana dinyatakan oleh Couts dkk bahwa bentuk - bentuk kekerasan yang dihadapi perempuan dalam kehidupan rumah tangga tidak hanya berupa kekerasan fisik, namun juga kekerasan psikologis seperti perilaku yang dikendalikan, penyalahgunaan ekonomi, maupun isolasi terhadap dunia luar atau kehidupan sosial) selain itu, kekerasan yang dihadapi oleh perempuan yakni kekerasan seksual. (Counts et al., 1999; Haj-Yahia, 2000; Heise et al., 1999; Michau \& Naker, 2003 dalam Sidibe dkk, 2006). Adanya pemahaman yang menganggap bahwa kekerasan dalam rumah tangga hanya berkaitan dengan kekerasan fisik perlu ditinjau ulang, karena perempuan sebagai manusia memiliki banyak dimensi tidak hanya fisik namun juga psikologis, sosial, ekonomi, religi dan lainnya, ketika perempuan mengadapi berbagai pembatasan, penghalangan atau pemaksaan terhadap dimensi-dimensi tersebut, hal tersebut masuk kategori kekerasan. Jadi kekerasan dalam rumah tangga tidak dapat disederhanakan hanya pada kekerasan fisik, namun juga kekerasan dalam berbagai bentuk lain seperti psikologis, ekonomi, sosial, dan lainnya.

Kekerasan yang dihadapi perempuan dalam kehidupan rumah tangga tidak sematamata karena kesalahan perempuan sebagai seorang pribadi. Namun, kondisi tersebut memiliki banyak faktor yang berakar pada budaya patriakhi dimana perempuan menempati posisi yang tidak setara dengan laki-laki. Menurut Azeez Oyediran kekerasan yang didapi perempuan dalam kehidupan rumah tangga dipicu oleh berbagai faktor baik pada tingkatan individual, micro, exo, dan pada tingkatan makro) menegaskan norma budaya yang membenarkan penggunaan hukuman dengan menggunakan kekerasan pada perempuan. Pada tingkatan individual, keterbatasan tingkat pendidikan perempuan dan rendahnya akses perempuan untuk memperoleh pekerjaan mewakili faktor ketidakmampuan perempuan. Pada tingkatan mikro 
Nunung Nurjanah, Bunyamin Maftuh, Elly Malihah Vol 5 No 1

ISSN : 2541-6995

E ISSN : 2580-5517

atau dalam konteks kehidupan rumah tangga, perempuan kurang memiliki otonomi dalam membuat keputusan mengenai barang-barnag yang dibeli untuk keperluan keluarga, memposisikan perempuan pada resiko menghadapi kekerasan rumah tangga, ketika barang yang dibeli tidak sesuai dengan apa yang dibolehkan atau dibenarkan untuk dibeli menurut suami. Pada tingkatan masyarakat yang lebih luas, lingkungan politik dan ekonomi (seperti terbatasnya layanan bantuan hukum bagi perempuan untuk memperoleh kehidupan yang lebih baik atau bagi perempuan yang menghadapi kegagalan dalam kehidupan keluarga untuk memperoleh dukungan) yang menegaskan berlangsungnya kekerasan dalam rumah tangga. (Azeez Oyediran dalam Genus, 2016). Jelas dipahami bahwa kekerasan yang dihadapi perempuan berasal dari berbabagai faktor yang tidak berdiri sendiri namun saling terkait satu sama lain, namun mata rantai kekerasan tersebut dapat diputus melalui pendekatan individual yakni dengan membuka akses pendidikan dan kesempatan bagi perempuan untuk terlibat pada ranah publik termasuk untuk mesuk dalam dunia kerja sehingga tidak tergantung secara finansial kepada suami yang sering menjadi pemicu terjadinya kekerasan pada perempuan. Namun, menurut Korabik dkk kekerasan yang dihadapi perempuan disebabkan oleh adanya perbedaan pekuasaan yang dimiliki oleh laki-laki dan perempuan bukan karena perbedaan gender. (Korabik et al., 1993; Randel, 2002; Watson and Hoffman, 1996; Stockard and Johnson, 1992 dalam Brahman et al 2005 : 201). Kekuasaan yang tidak setara yang dimiliki laki-laki dan perempuan menjadi pemicu terjadinya kekerasan dalam rumah tangga, dan karena pempuan memiliki akses yang terbatas pada berbagai sumber daya sehingga kekuasaan lebih banyak didominasi oleh laki-laki dan perempuan berada pada posisi subordinat dengan kekuasaan yang terbatas. Atas dasar tersebut, sebenarnya laki-laki tidak selalu sebagai pelaku kekerasan dalam rumah tangga, namun perempuan (yang memiliki kekuasaan) dapat menjadi pelaku kekerasan dalam rumah tangga. Sebagaimana dinyatakan oleh Jackson bahwa baik lakilaki maupun perempuan merupakan korban dan pelaku, namun menjadi perdebatan terkait dengan apakah kekerasan yang dilakukan laki-laki sama dengan kekerasan yang dilakukan oleh perempuan. (Jackson, 1999 : 47). Meskipun laki-laki maupun perempuan dapat menjadi pelaku dan korban kekerasan dalam rumah tangga, namun keterbatasan perempuan dalam memperoleh akses posisi yang setara dengan laki-laki terbatas dikarenakan sejak awal perempuan menghadapi berbagai macam belenggu yang melekat sejak awal kehidupan mereka sebagai seorang perempuan, sehingga perempuan memiliki kesempatan terbatas untuk memiliki kekuasaan. Sebagaimana dinyatakan oleh Jawkes bahwa kekerasan terhadap 
perempuan menunjukan kekuasaan yang dimiliki laki-laki atas perempuan yang memiliki posisi subordinat karena memiliki kekuasaan yang tidak setara (lebih rendah) dengan laki-laki. Perempuan memiliki status yang rendah dan perempuan seringkali memiliki persepsi diri yang randah serta kemampuan ssosial ekonomi yang rendah sehingga sukar meninggalkan suatu hubungan (yang menempatakan perempuan sebagai korban kekerasan domestik), dan kembali kepada keluarga mereka atau hidup sendiri, kondisi ini yang menjadikan perempuan dengan semua kemampuan yang dimiliki untuk menentang pelaku kekerrasan. (Jewkes, 2002 : 1427). Kondisi sosial ekonomi yang lemah seringkali membatasi pilihan perempuan untuk mampu mengambil keputusan melawan atau tidak membiarkan kekerasan terus dilakukan padanya. hasil penelitian yang dilakukan oleh Kennedy yang menyatakan bahwa ketidasetaraan ekonomi dalam kontkes masyarakat miskin menjadi suatu yang lebih penting dibadingkan dengan tingkat pendapatan absolut atau pemberdayaan laki-laki maupun perempuan dalam suatu hubungan. Dalam hal ini, kekerasan merupakan suatu produk dari relasi yang tidak setara diantara pihak yang terlibat dalam konflik. Ketidak adilan sosial ekonomi dalam suatu komunitas atau masyarakat menjadi pemicu penting munculnya kekerasan dalam bentuk lain. (Kennedy, 1997).

Kekerasan yang dialami perempuan dalam kehidupan rumah tangg tidak dapat dilepaskan dari dari norma sosial budaya yang berlaku pada masyarakat tersebut. Hasil penelitian Azeez Oyediran menunjukan bahwa kekerasan terhadap perempuan dalam keluarga berkaitan dengan faktor demografi dan sosial budaya, dimana masyarakat meyakini kekerasan terhadap perempuan dalam konteks keluarga dibenarkan atau diperbolehkan khususnya oleh agama, dan wilayah (perkotaan maupun pedesaan) faktor tersebut memiliki pengaruh yang sama selama bertahun-tahun. Faktor demografi dan sosial budaya memiliki peran penting terhadap terjadinya kekerrasan dalam rumah tangga dan seharunya menjadi dasar bagi pembuat kebijakan yang ditujukan untuk mengatasi kekerasan berbasis gender, termasuk kekerasan dalam rumah tangga. (Azeez Oyediran, 2016 : 23). Agama secara khusus seringkali menjadi legitimasi atas kekerasan dalam rumah tangga. Untuk mengatasi persoalan tersebut, para pembuat kebijakan harus memperhatikan aspek sosial kultural sehingga upaya menatasi kekerasan berbasis gender dapat diatasi dengan dukungan semua pihak khususnya masyarakat dimana norma sosial budaya (yang melegitimasi kekerasan berbasis gender) dapat diatasi. 


\section{Organisasi Perempuan Dan Peran Dalam Melakukan Mediasi konflik kekerasan dalam} keluarga

Menyelesaikan konflik dalam keluarga seringkali tidak cukup hanya melibatkan pihak yang berkonflik atau keluarga dari kedua belah pihak, diperlukan keterlibatan pihak lain karena manakala penyelesaian konflik hanya melibatkan pihak terkait beserta keluarga masing-masing pihak, maka akan diharapkan pada perbedaan persepsi dan sudut pandang yang seringkali bersumber dari berbagai perbedaan baik nilai budaya yang dianut, gender, maupun perbedaan lain yang mengikuti. Sebagaimana dinyatakan oleh Brahnam dkk bahwa terkadang penyelesaian konflik terhambat karena adanya hambatan budaya, kelas, etnik, gender, maupun hambatan lainnya, sehingga diperlukan pihak ketiga untuk membantu pihak yang berkonflik dalam menyelesaikan konflik tersebut. (Brahnam, 2005 : 89). Organisasi perempuan dapat menjadi pihak ketiga yang menengahi konflik keluarga, peran sebagai mediator oleh organisasi perempuan dapat dilakukan secara netral dengan memposisikan laki-laki dan perempuan secara setara dengan hak yang sama dan mencoba menyelesaikan persoalan dengan berbasis nilai kesetaraan gender.

Persoalan kekerasan dalam rumah tangga bukan semata dipicu oleh persoalan personal dalam lingkup keluarga, namun kekersan dalam rumah tangga berakar pada nilai budaya patriakhi yang dipahami oleh masyarakat dilegitimasi oleh agama. Atas dasar tersebut, tokoh agama berperan dalam menyelesaikan konflik berupa kekerasan dalam rumah tangga. Sebagaiama dinyatakan oleh Mayer \& Bass bahwa pemimpin politik dan agama, orang-orang tua, dan tokoh masyarakat memiliki sumber daya yang penting terkait pengaruh mereka dalam menyelesaikan kekerasan domestik melalui mediasi. (Mayer, 2000 : 191). Penyelesaian kekerasan dalam rumah tangga melalui mediasi sebagai salah satu pilihan yang dapat dilakukan untuk menengahi konflik berupa kekerasan dalam rumah tangga dengan melibatkan tokoh agama, politik, maupun tokoh masyarakat sebagai pihak-pihak yang dianggap "legitimate", sehingga kekerasan tersebut tidak lagi terulang. Dalam melakukan mediasi yang berbasis gender, mediator diharapkan tidak semata memposisikan diri secara netral, namun mediator harus membantu pihak-pihak yang terkait agar kepentingannya terpenuhi. Dinyatakan oleh Mayer bahwa pada dasarnya, pihak - pihak yang terkait dalam konflik dalam hal ini berkenaan dengan kekerasan dalam rumah tangga yang sering memposisikan perempuan sebagai korban dan laki-laki sebagai pelaku mengharapkan mediator untuk membantu mereka untuk 
Nunung Nurjanah, Bunyamin Maftuh, Elly Malihah Vol 5 No 1

ISSN : 2541-6995

E ISSN : 2580-5517

memenuhi kebutuhan atau kepentingan mereka. Mediator perlu memperhatikan kebutuhan para pihak yang berkonflik (kekerasan dalam ranah domestik) untuk rasa aman, dihargai, dan didengar, meskipun orientasi utama mediator yakni untuk mencapai hasil yang terbaik untuk semua pihak. (Mayer, 2000 : 194). Dalam melakukan mediasi untuk membantu menyelesaikan konflik termasuk konflik kekerasan dalam rumah tangga, mediator menciptakan kondisi yang memungkinkan diperolehnya keputusan yang terbaik bagi semua pihak dengan memberikan rasa aman semua pihak terkait, dihargai, dan didengarkan.

Mediator harus menepatkan pihak yang berkonflik secara setara (equal), dan memfasilitasi untuk mengasilkan solusi terbaik bagi semua pihak. Dibutuhkan tidak sekedar kemampuan untuk memediasi kepentingan semua pihak, namun mediator perlu memiliki pemahaman yang mendalam mengenai aspek sosial kultural yang seringkali melandasi munculnya konflik tersebut, sehingga keputusan yang diperoleh mencerminkan rasa keadilan bagi semua pihak. Yang sering terjadi yakni pihak yang melakukan mediasi konflik kekerasan dalam rumah tangga khususnya pihak keluarga tidak dalam posisi netral namun memihak pada salah satu pihak dan keputusan yang diambil dilansakan pada nilai dan norma yang hanya menguntungkan satu pihak. Dinyatakan oleh Mayer bahwa moderator dari organisasi, orang tua atau keluarga dari pihak yang berkonflik yang berusaha menengahi konflik kekerasan dalam rumah tangga yang terjadi seringkali tidak bertindak netral atau imparsial. Oleh karena itu, yang diperlukan oleh moderator yakni berusaha untuk membantu pihak-pihak yang terkait untuk saling berinteraksi antar para pihak yang terlibat konflik secara lebih efektif atau membantu menyusun kesepakatan yang dapat diterima oleh semua pihak. (Mayer, $2000: 200$ ). Moderator dari pihak diluar keluarga seringkali diperlukan untuk menghindari subyektifitas maupun konflik kepentingan. Moderator luar dapat mengambil "jarak" dari pihak yang berkonflik dengan memfasilitasi masukan yang terbaik bagi semua pihak dan memposisikan pihak - pihak yang berkonflik (suami isteri) secara imparsial. Dalam konteks kekerasan dalam rumah tangga, moderator menenpatkan suami dan isteri pada posisi yang setara, memiliki hak yang sama dan memperoleh penghargaan yang sama sehingga solusi atas konflik yangterjadi mengakomodir pandangan, pebutuhan, maupun hak semua pihak sehingga diperoleh solusi secara adil.

Keberadaan organsiasi perempuan atau nongoverment organization yang berperan mengadvokasi dan mengedukasi perempuan dalam mengahadapi kekerasan dalam keluarga 
sangat berbarti bagi perempuan untuk memperoleh dukungan maupun pendampingan. Keberadaan organisasi perempuan sangat berbarti bagi perempuan sebagai "tempat bersandar" dan tidak merasa sendiri manakala menghadapi berbagai kekerasan dalam ranah domestik. Sebagaimana dinyatakan oleh Agerberg \& Kathrin bahwa perempuan perempuan memiliki keterbatasan dalam menanggapi ancaman kekerasan seksual, ancaman ini dikaitkan dengan pola yang lebih luas yakni berkenaan dengan diskriminasi dan penindasan di masyarakat. Perempuan dapat bergabung dengan kelompok swadaya, asosiasi korban, atau organisasi nonpemerintahan (NGOs) yang berperan dalam meloby pemerintah untuk dapat memperluas perlindungan terhadap perempuan, membantu para korban (kekerasan) termasuk korban kekerasan seksual. (Agerberg \& Kathrin Kreft, 2019 : 9). Perempuan tidak dapat menghadapi sendirian persoalan kekerasan yang dihadapinya, karena persoalan tersebut tidak semata-mata persoalan personal, namun merupakan persoalan kultural bahkan struktural. Atas dasar itu, perempuan perlu bergabung dengan berbagai organisasi atau asosiasi yang memberikan perlindungan dan memperjuangkan kepentingan perempuan secara formal dengan melobi pemerintah. Diperlukan konsistensi dan upaya kolektif dalam berbagai bentuk organisasi atau asosiasi yang mendukung kesetaraan gender sehingga konflik yang muncul dari ketidakadilan gender dapat diatasi. Partisipasi perempuan dalam memperjuangkan haknya untuk terlindungi dan terbebas dari kekerasan termasuk kekerasan dalam rumah tangga. Dinyatakan oleh Domingo dkk bahwa banyak asosiasi yang berskala kecil dan bersifat informal memperluas aktifitas mereka dan membuat jejaraing formal yang ditujukan untuk memperluas penerapan prinsip kesetaraan gender, perlindungan terhadap perempuan dari kekerasan berbasis gender, serta untuk memperluas partisipasi perempuan dalam penyusunan berbagai perundangan baru yang mengakomodir kepentingan perempuan. (Domingo et al, 2019 : 21). Organisasi perempuan berperan baik pada tataran informal yakni memfasilitasi dan memberikan pendampingan pada perempuan korban kekerasan (termasuk kekerasan dalam rumah tangga) salah satunya menjadi mediator konflik dalam rumah tangga, disamping secara formal berupaya mendorong terpenuhinya perlindungan perempuan secara hukum.

Salah satu peran yang dapat dilakukan oleh organisasi perempuan dalam memberikan perlindungan bagi perempuan termasuk agar terhindar dari kekerasan yakni dengan memberikan edukasi yang memadai agar perempuan paham akan hak nya untuk terbebas dari kekerasan. Dinyatakan oleh Osuchukwu bahwa perempuan memiliki hak untuk diberdayakan melalui informasi dan memperoleh kekuatan sehingga dapat menyelesaikan persoalan mereka 
Nunung Nurjanah, Bunyamin Maftuh, Elly Malihah Vol 5 No 1

ISSN : 2541-6995

E ISSN : 2580-5517

sendiri dan membangun masa depan mereka sendiri dengan lebih baik. Perempuan perlu diberikan kesempatan bagi perempuan untuk "berbicara" menyuarakan kepentingan dan hak perempuan dan perempuan perlu memperoleh jaminan atas kehidupan yang baik secara berkelanjutan termasuk dalam kehidupan rumah tangga mereka. (Osuchukwu, 2015 : 432). Organisasi perempuan memiliki berbagai peran dalam memberikan perlindunga bagi perempuan, baik melalui permberdayaan dan edukasi pada perempuan dengang memberikan akses informasi yang diperlukan sehingga perempuan berdaya dalam menjalankan kehidupannya sebagai pribadi maupun dalam kehidupan keluarga. Manakala perempuan menghadapi konflik kekerasan, organsiasi dapat memfasilitasi upaya mediasi sehingga konflik yang terjadi dapat terselesaikan dengan hasil yang diupayakan memberikan yang terbaik bagi semua pihak yang berkonflik baik laki-laki maupun perempuan.

\section{KESIMPULAN}

Kekerasan dalam rumah tangga merupakan suatu realitas sejarah yang hingga saat ini masih terus berlangsung, termasuk pada masyarakat modern. Laki-laki dan perempuan menjadi pelaku dan korban kekerasan dalam rumah tangga, namun korban terbanyak yakni perempuan. Kondisi ini menggambarkan bahwa kekerasan dalam rumah tangga bukan suatu kondisi yang berdiri sendiri yakni hanya merupakan persoalan internal keluarga, yang terlepas dari sistem sosial budaya masyarakatnya. Sistem budaya patriakhi yang melekatkan peran, fungsi dan tanggung jawab berbeda pada laki-laki dan perempuan, dengan membuat sekat peran bagi lakilaki diranah publik dan perempuan diranah privat yang berimbas pada relasi yang tidak setara menjadi akar kekerasan dalam rumah tangga.

Ketidakadilan gender sebagai kondisi yang tidak dapat dihindari manakala laki-laki dan perempuan memiliki akses yang berbeda dalam berbagai bidang kehidupan, termasuk dalam pendidikan, sehingga tercipta ketergantungan satu pihak, dalam hal ini perempuan (yang memiliki akses terbatas) terhadap laki-laki termasuk dalam konteks rumah tangga, kondisi tersebut seringkali menjadi pemicu konflik dengan kekeasan dalam rumah tangga.

Konflik dengan kekerasan dalam rumah tangga dipicu oleh berbagai faktor yang berakar pada budaya patriakhi. Perempuan sebagai seorang pribadi yang sejak awal kehidupan disosialisasikan untuk berperan sebagaimana yang ditentukan dalam budyaa patriakhi yakni hanya diwilayah domestik, sehingga perempuan tidak perlu mengakses pendidikan maupun terlibat dalam kegiatan ekonomi, sosial dan lainnya karena perempuan harus mengabdikan 
Nunung Nurjanah, Bunyamin Maftuh, Elly Malihah Vol 5 No 1

ISSN : 2541-6995

E ISSN : 2580-5517

hidupnya untuk urusan rumah tangga, hal ini menyebabkan perempuan memiliki keterbatasan pengetahuan, keterampilan maupun keahlian yang menyebabkan perempuan tergantung pada laki-laki (ayah maupun suami). Ketergantungan perempuan terhadap pasangannya karena keterbatasan pengetahuan, keahlian maupun keterampilan yang dimiliki (soft skills dan hardskills) berpotensi memicu konflik dengan kekerasan di keluarga. Disamping faktor individu, faktor lainnya yakni faktor mikro yang memicu konflik dengan kekerasan dalam rumah tangga hal ini berkenaan dengan otoritas laki-laki sebagai kepala rumah tangga yang memiliki kekuasaan dalam membuat keputusan mengenai semua hal yang berkenaan dengan urusan rumha tangga, dalam hal ini, perempuan tidak memiliki otonomi karena perempuan hanya harus mengikuti keputusan yang dibuat oleh suami. Manakala perempuan membuat pilihan atau keputusan sendiri berkenaan dengan urusan rumah tangga termasuk dalam barangbarnag yang dibeli, maka tindakan tersebut dianggap sebagai kesalahan karena dianggap tidak tunduk pada suami sehingga layak untuk dihukum sebagai sanksi sekaligus peringatan agar tidak mengulang "kesalahan” yang sama. Faktor lain yang memicu konflik dengan kekerasan dalam rumah tangga yakni faktor makro, hal ini berkenaan dengan pengaruh lingkungan yang lebih luas yakni masyarakat dengan sistem yang menopang budaya patriakhi sehingga struktur maupun kultur yang dibangun tidak memberikan posisi yang setara antara laki-laki dan perempuan.

Penyelesaian konflik dengan kekerasan dalam keluarga perlu melibatkan piahk ketika yang memiliki perpektif kesetaraan gender, karena konflik yang muncul bermuara pada budaya patriakhi yang melahirkan ketidakadilan gender. mediator dalam menyelesaikan konflik dengan kekerasan dalam keluarga dapat diambil oleh organisasi perempuan karena organisasi perempuan memiliki peran sebagai mediator yang dapat memposisikan laki-laki dan perempuan secara setara.

\section{Daftar Pustaka}

Agerberg, Mattias and Kathrin Kreft, Anne. 2019. Gendered Conflict, Gendered Outcomes: The Politicization of Sexual Violence and Quota Adoption. Journal of Conflict Resolution 128. 
Nunung Nurjanah, Bunyamin Maftuh, Elly Malihah Vol 5 No 1

ISSN : 2541-6995

E ISSN : 2580-5517

Brahnam, Sheryl D. et al. 2005. Journal of Management Development . Vol. 24 No. 3. Emerald Group Publishing Limited 0262-1711. DOI 10.1108/02621710510584026.

Genus, Oyediran. 2016. Explaining trends and patterns in attitudes towards wife-beating among women in Nigeria: analysis of 2003, 2008, and 2013 Demographic and Health Survey data. DOI 10.1186/s41118-016-0016-9.

Jackson SM. 1999. Issues in the dating violence research: a review of the literature. Aggress Violent Behav.

Jalusic, V. .2002. ‘. The European Journal of Women Studies 9(2):103-122.

Kennedy BP, Kawachi I. 1997. Health and social cohesion: why care about income inequality? BMJ. 314. 1037-40.

Kymlicka, Will. 1995. Multicultural Citizenship A Liberal theory of Minority Rights. Oxford University Press. New York.

Margono. 2010. Metodologi Penelitian Pendidikan. Rieneke Cipta. Jakarta

Mayer, Bernard. 2000. The dynamic of conflict resolution. Jossey-Bass. San Francisco.

Osuchukwu, Gozi P., Udeze Nkechi S. 2015. Promoting Women's Participation In Conflict Resolution In Nigeria: Information Accessibility. International Journal of Social Science and Humanities Research ISSN 2348-3164 (online) Vol. 3, Issue 4, pp: (431-439), Month: October - December 2015, Available at: www.researchpublish.com.

Rachel Jewkes. 2002. Intimate partner violence: causes and prevention. The Lancet. Vol 359. www.thelancet.com.

Sidibe et al. 2006. Domestic violence against women in Egypt-wife beating and health outcomes. Social Science \& Medicine 62. 1260-1277.

Zed, mestika. 2014. Metode penelitian pustaka. Yayasan Pustaka Obor. Jakarta. 